\title{
ЕКОНОМІЧНА БЕЗПЕКА УКРАЇНИ КРІЗЬ ПРИЗМУ ЕНЕРГЕТИЧНОЇ СТРАТЕГІї
}

\section{ЭКОНОМИЧЕСКАЯ БЕЗОПАСТНОСТЬ УКРАИНЫ СКВОЗЬ ПРИЗМУ ЭНЕРГЕТИЧЕСКОЙ СТРАТЕГИИ}

\section{ECONOMIC SECURITY OF UKRAINE THROUGH THE PRISM OF THE ENERGY STRATEGY}

\begin{abstract}
Розглянуто складові економічної безпеки країни. Виявлений зв'язок між економічною та енергетичною безпекою. Виділено компоненти економічної та енергетичної безпеки в Україні. Виявлено внутрішні та зовнішні загрози енергетичній безпеці. Дано оцінку енергетичному балансу країни у світлі політичних подій на Донбасі та в АР Крим. Проведено аналіз енергетичного потенціалу України у розрізі окремих видів енергії. Розкрито перспективи розвитку паливно-енергетичного комплексу країни згідно до умов Договору про входження до Енергетичного Співтовариства. Проаналізовано можливості для розвитку торговельних відносин українських i європейських газових трейдерів, згідно з правилами Третього енергетичного пакету. Дано оцінку Енергетичній стратегії України. Окреслено напрями розбудови енергетичної інфраструктури. Відображено шляхи узгодженості держаної політики енергобезпеки у всіх сегментах ii впливу: добування і відновлення енергоресурсів, транспортування i розподіл, використання. Запропоновані основні напрямки стабілізації економічної безпеки країни через удосконалення окремих положень Енергетичної стратегії.

Ключові слова: економічна безпека, енергетична безпека, енергетична стратегія, загрози, енергоносії, енергоємність, диверсифікація
\end{abstract}

Рассмотрены составляющие экономической безопасности страны. Выявлена связь между экономической и энергетической безопасностью. Выделены компоненты экономической и энергетической безопасности в Украине. Выявлены внутренние и внешние угрозы энергетической безопасности. Дана оценка энергетическому балансу страны в свете политических событий на Донбассе и в AP Крым. Проанализирован энергетический потенциал Украины в разрезе отдельных видов энергии. Раскрыты перспективы развития топливно-энергетического комплекса страны в соответствии с условиями Договора о вхождении в Энергетическое Сообщество. Дана оценка Энергетической стратегии Украины. Проанализированы возможности для развития торговых отношений украинских и европейских газовых трейдеров, согласно правилам Третьего энергетического пакета. Определены направления развития энергетической инфраструктуры. Отражены пути согласованности государственной политики энергобезопасности во всех сегментах ее влияния: добыча и восстановление энергоресурсов, транспортировка и распределение, использование. Предложены основные направления стабилизации экономической безопасности страны путем усовершенствования отдельных положений Энергетической стратегии.

Ключевые слова: экономическая безопасность, энергетическая безопасность, энергетическая стратегия, угрозы, энергоносители, энергоемкость, диверсификация. 
The components of economic security of the country are considered. The relationship between economic and energy security is revealed. The components of economic and energy security of Ukraine are selected. En internal and external threats to energy security are detected. The estimate of the energy balance of the country in light of political developments in the Donbas and Crimea is given. The energy potential of Ukraine in the context of certain types of energy is analyzed. Reveals the prospects of development of fuel and energy complex under the terms of the Treaty on the European Energy Community. The possibilities for the development of trade relations Ukrainian and European gas traders, according to the rules of the Third Energy Package are analyzed. The Energy Strategy of Ukraine is evaluated. The areas of building energy infrastructure are outlined. It's displaying ways consistency of state energy policies in all segments of its impact, energy extraction, transportation, distribution, use, recovery. The basic directions of stabilization of economic security by improving certain provisions of the Energy Strategy are proposed.

Keywords: economic security, energy security, energy strategy, threats, energy, energy consumption, diversification.

Вступ. У системі сталого розвитку енергетика виступає важливим фактором, що здійснює безпосередній вплив на виробничі відносини, соціальний розвиток суспільства, стан довкілля. Обмеженість енергоресурсів вимагає їх оцінювання у статусі фактора економічної безпеки та врахування при формуванні національних та підприємницьких стратегій. Концепція енергобезпеки, як доступність енергоресурсів для промислового та побутового споживання дістала широкого поширення у наукових працях. Разом 3 тим рушійною силою будь-якого процесу виступає стратегічне бачення, що вибудовує систему цілей та розробляє конкретні заходи, спрямовані на подолання проблемних ділянок у траєкторії досягнення результативних рішень.

Дослідженнями зазначеної проблематики охоплена ціла плеяда дослідників, практиків: Земляний М.Г. [1], Лойко В.В. [2], Микитенко В.В. [3], Прейгер Д.К. [4], Сабадаш В.В. [5], Суходоля О.М. [6].

Сутнісні аспекти енергетичної безпеки, іiі місце у системі економічної безпеки підняті у працях Лойко В.В., Микитенко В.В., Прейгера Д.К. [2-4], методичні підходи до оцінювання рівня економічної безпеки представлені у працях Земляного М. Г. [1]. Питання державного управління енергобезпекою, прикладних аспектів досягнення стратегічних цілей розкриваються у працях Суходолі О.М. [6]. Разом 3 тим у проведених дослідженнях не у повній мірі проведена ревізія співвідношення стратегічних цілей та енергетичного потенціалу країни.

Постановка завдання. Метою даного дослідження є формування комплексу стратегічних цілей забезпечення мінімального і максимального рівнів енергетичної безпеки України 3 метою підвищення енергоефективності економіки та пошуку альтернативних постачальників енергоносіїв. Для досягнення зазначеної мети поставлені такі завдання: виділити компоненти економічної та енергетичної безпеки в Україні; виявити внутрішні та зовнішні загрози енергетичній безпеці; проаналізувати енергобаланс країни у світлі політичних подій на Донбасі та у АР Крим; 
обгрунтувати заходи для підвищення енергетичної безпеки України, спрямованих на підвищення ефективності економіки в цілому.

Методологія. Методологічною основою дослідження $є$ офіційні статистичні дані, звітні аналітичні дані, наукові праці. Для обробки зазначеної інформації використовуються методи: абстрагування, аналіз, синтез, опис, інтерпретація та інші.

Результати дослідження. Поняття економічної безпеки відображає рівень захищеності інтересів підприємства, держави, суспільства завдяки наявності достатніх ресурсів для задоволення базових та додаткових потреб. Звичайно, що для кожної групи стейкхолдерів компонентний склад та цілі економічної безпеки будуть відрізнятися.

Складовими економічної безпеки виступають: інвестиційна, інноваційна, фінансова, енергетична, зовнішньоторговельна, демографічна тощо. Оскільки рушійною силою прогресу є енергоресурси, то енергобезпеці відводиться вагоме місце у системі економічної безпеки.

Енергобезпека - це комплексне поняття, що охоплює декілька рівнів, а саме: політичний (енергонезалежність держави чи регіону), техногенний (шкода, завдану життю, здоров'ю, працездатності осіб, майну, навколишньому середовищу), економічний (цінова політика та стратегічні запаси енергоресурсів), соціальний (доступній енергоспоживання для населення).

Зупинимось на окремих компонентах економічної енергобезпеки України. Інтегрованість України у світогосподарські зв'язки продукує низку ризиків економічного, політичного, технічного, технологічного характеру. Відсутність дієвих кроків щодо структурної перебудови економіки призводить до високої енергоємності ВВП. Не зважаючи на те, що мають місце певні позитивні зрушення у цьому напрямі - енергоємність ВВП знизилася з 0,820 кг. у.П. на гривню продукції у 2003 р. до 0,613 у 2013 р., цей показник майже у 4 рази вищий ніж у країнах $\mathrm{CC}$.

Згідно з дослідженням динаміки показника енергоємності ВВП України у цінах 2005 р., прийнятого за базовий, для усунення інфляційних впливів ВВП (рис. 1), бачимо, що даний індикатор не зменшувався нижче позначки 0,4 кг У. п./грн.

Україна $\epsilon$ одним з найкрупніших споживачів газу в Європі. За даними 2013 р. загальний обсяг споживання склав 50,3 млрд. кубометрів. 3 них на потреби промислового сектору було витрачено 20 млрд. кубометрів. Ще 9 млрд. витратили на тепло генерацію. 


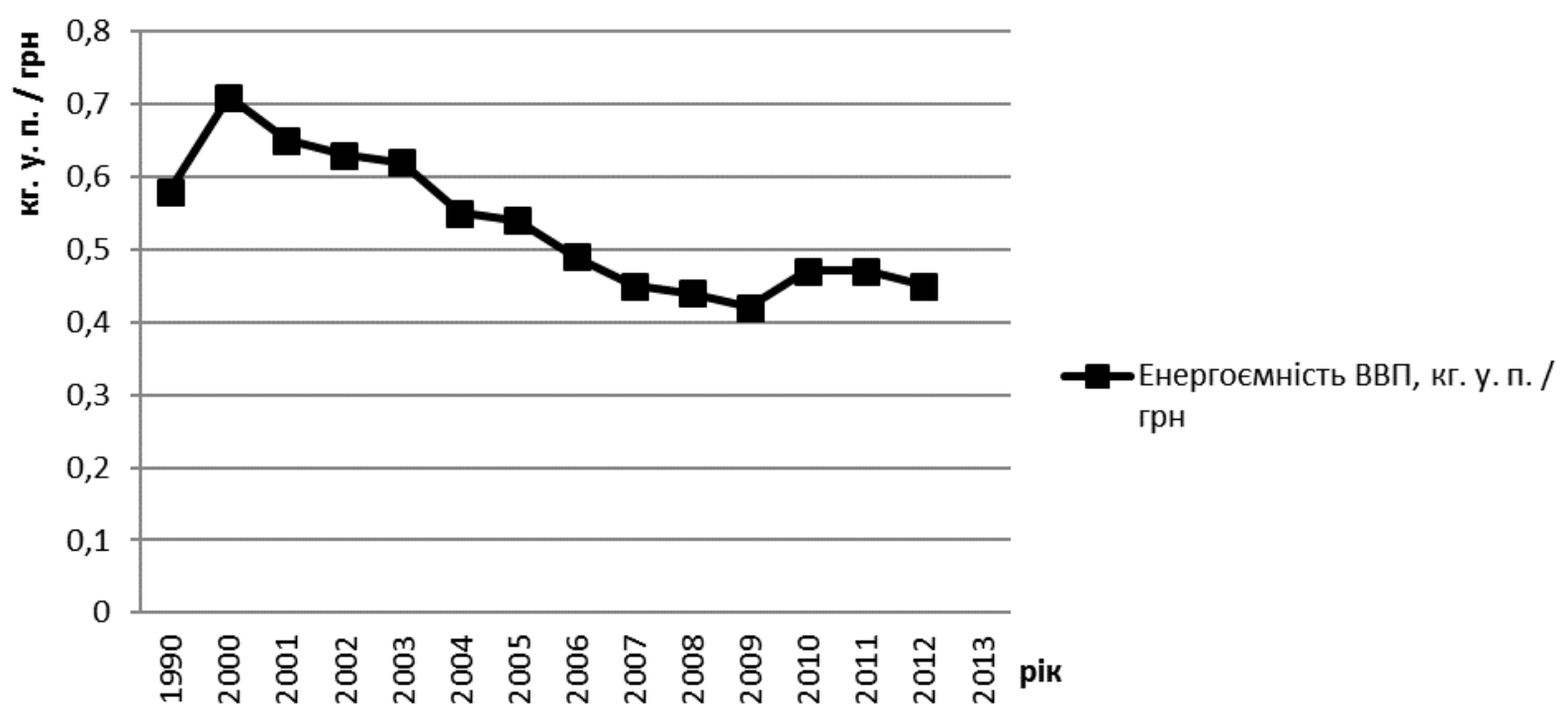

Рис. 1. Енергоємність ВВП України, кг У. п./грн. [7]

Окрім високої енергоємності ВВП України, іiі енергетичний сектор стикається з іншими великими проблемами, починаючи з високої залежності від імпорту дорогого викопного палива, таких як нафта і газ, до неефективної інфраструктури ринків.

Маючи 52 ГВт встановлених генеруючих потужностей, з яких у пікових ситуаціях використовується щонайбільше 32 ГВт, об'єднана енергетична система (ОЕС) України періодично не справляється 3 навантаженням i змушена закривати баланс за рахунок поставок електроенергії з Російської Федерації. Окреслені вище критичні моменти формують систему загроз енергетичній безпеці України та вимагають прийняття термінових та ефективних рішень (таблиця).

Таблиця

Система загроз енергетичній безпеці України

\begin{tabular}{|c|c|}
\hline Внутрішні загрози & Зовнішні загрози \\
\hline $\begin{array}{l}\text { - Недостатня забезпеченість викопними } \\
\text { ресурсами, } \\
\text { - Нераціональне використання енергоносіїв, } \\
\text { що призводить до їх дефіциту; } \\
\text { - Незадовільний технічний стан основних } \\
\text { фондів, загрози аварій і тероризму на об'єктах } \\
\text { ПЕК; } \\
\text { - Соціальна напруга, викликана підвищенням } \\
\text { цін на енергоносії, високою аварійністю } \\
\text { виробництва на підприємствах ПЕК; } \\
\text { - Недоліки державної енергетичної політики }\end{array}$ & $\begin{array}{l}\text { - Несприятлива кон’юнктура ринку; } \\
\text { - Масштабні аварії на об’єктах ПЕК, } \\
\text { викиди парникових газів; } \\
\text { - Протиріччя у геополітичних } \\
\text { інтересах країн; } \\
\text { - Відсутність } \\
\text { диверсифікації серед постачальників } \\
\text { енергоресурсів; } \\
\text { - Політична нестабільність та } \\
\text { військові конфлікти у зонах } \\
\text { зосередження енергоресурсів }\end{array}$ \\
\hline
\end{tabular}


Вище описаний комплекс загроз дає змогу дослідити стан енергетичної галузі і одночасно структурувати поняття енергетичної безпеки. На його основі нами запропоновано енергетичну стратегію гарантування енергетичної безпеки, сформовану у вигляді комплексу цілей забезпечення енергетичної безпеки у чотирьох напрямах діяльності: технічному, екологічному, економічному та геополітичному (рис. 2). Вертикальна стрілка вказує рівні енергобезпеки. Якщо мінімальним рівнем безпеки вважається зменшення споживання, то на вищих рівням ми оперуємо такими критеріями як: розвиток, збалансування, підвищення, забезпечення, покращення тощо. Зміна якісного рівня оцінювання відповідає відповідним етапам стратегічного планування, о базується на поступовій реалізації усього спектру заходів, спрямованих на посилення енергетичної, а відтак економічної безпеки країни.

Відповідно, втілення запропонованих заходів сприятиме підвищенню рівня енергетичної безпеки як динамічної категорії i економічної ефективності використання енергоресурсів в довгостроковій перспективі, виходячи з внутрішніх потреб в них і використанні зовнішніх джерел.

В енергетичному балансі нашої держави за 2013 рік природний газ займав 34,8\%, продукти вугільної промисловості, - 34,6\%, а атомна енергетика, відповідно, - 19,2\%. За офіційними енергетичними джерелами Україна має високий рівень залежності від російських постачальників: атомна енергетика, - близько $95 \%$ поставок палива для українських АЕС здійснює російська паливна компанія «ТВЕЛ»; газ, - близько $60 \%$ газу щороку імпортувалось із Росії; вугільна промисловість, - в результаті бойових дій на Сході та окупації територій Луганщини і Донеччини втрачено понад $75 \%$ вугільного потенціалу, що змусило український уряд закуповувати вугілля в ПАР та оперативно переводити виробництво теплової енергії на альтернативні джерела та електроенергетику [8].

Тож проблема полягає в тому, що наша країна отримує основні обсяги вуглеводнів безпосередньо $з$ одного джерела - Росії, або ж закуповувані енергоносії потрапляють в Україну транзитом через російську територію. Відповідно до міжнародної практики, таких незалежних один від іншого джерел повинно бути три-чотири, а прихильність поставок тільки до однієї країни криє в собі загрозу політичної незалежності в цілому.

Як зазначено в Аналітичній доповіді Центра Разумкова [12, с.2], вирішення проблеми енергоефективності в Україні нерозривно пов'язане 3 усуненням “сірих" схем міждержавної торгівлі енергоносіями, з відмовою від політики “дешевої робочої сили”, з диверсифікацією джерел постачання газу.

При наявних генеруючих потужностях та розвиненій мережі електропередачі, Україна має тісну залежність від зовнішніх джерел постачання енергоресурсів.

Експерти констатують, що за умов політичної кризи, найчутливішою для України $є$ енергетична сфера, де за найжорсткіших сценаріїв можливі такі дії Російської Федерації [13]: відмова від поставок природного газу через заборгованість за газ або невиконання контрактних зобов'язань; відмова від 


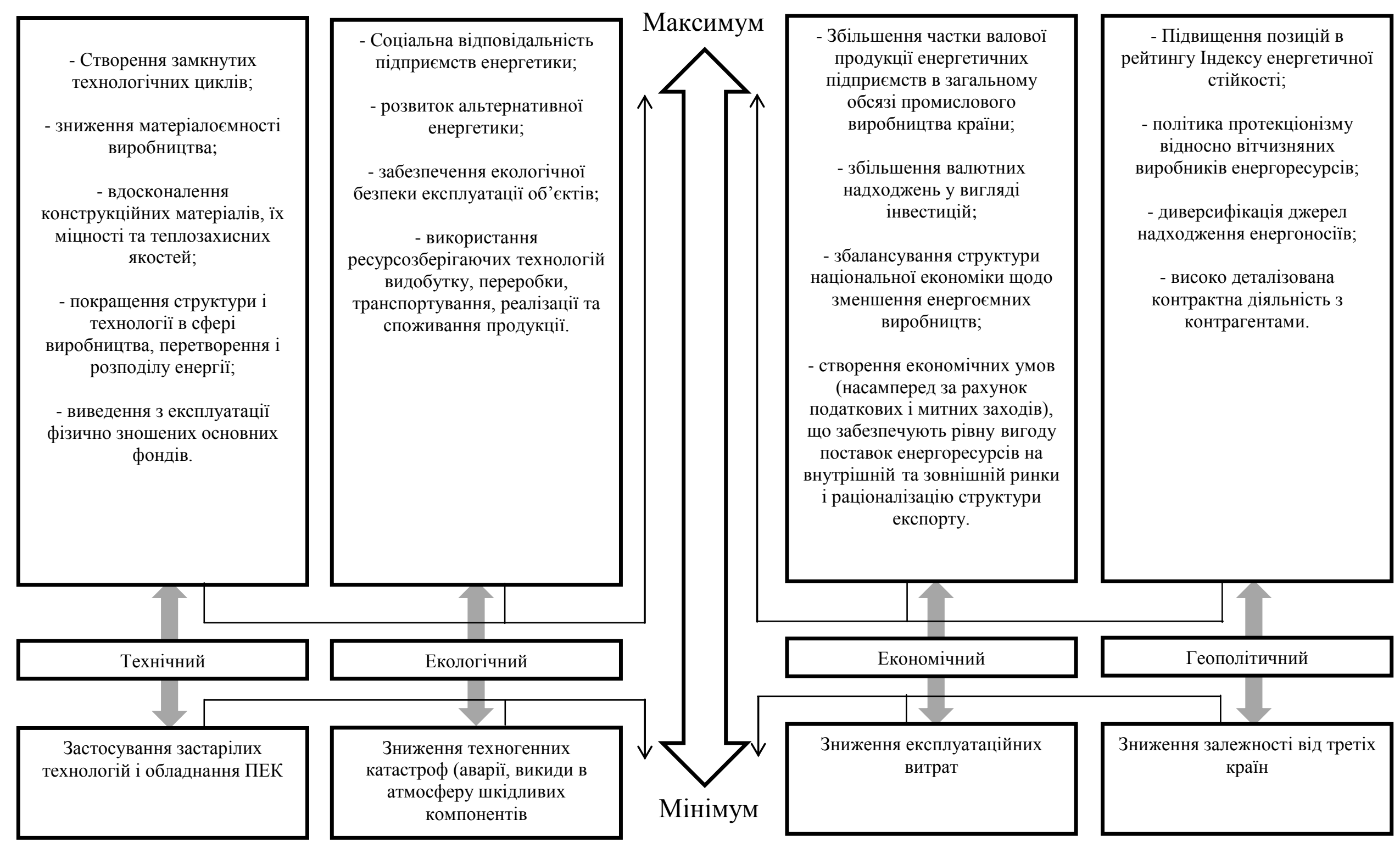

Рис. 2. Комплекс стратегічних цілей забезпечення мінімального і максимального рівня енергетичної безпеки України Джерело: розроблено авторами на основі [9;10;11] 
поставок нафти й нафтопродуктів країнами Митного союзу; відмова від поставок і зберігання відпрацьованого ядерного палива для АЕС i від паралельної роботи Об'єднаної енергетичної системи (ОЕС) України 3 енергосистемами країн СНД.

Оскільки розміщення електромереж України було спроектовано у системі кооперації Радянського Союзу, воно не дозволяє ефективно розподілити вироблену електроенергію.

У країні мають місце енергонадлишкові західні регіони та енергодефіцитні південні й південно-східні. Проектне навантаження електромереж складає 240 млрд кВт·год, проте вони ледь розподіляють 50 млрд кВт·год.

Надлишок базових і дефіцит маневрових потужностей (при потребі 15\% $€$ лише 8\%) вимагає для регулювання функціонування енергосистеми використовуються енергоблоки теплових електростанцій (ТЕС), які для цього не призначені. Надпланові режими роботи призводять до прискореного зношення основних фондів ТЕС, яке на сьогодні складає близько 80\%.

Власними паливними ресурсами для виробництва електроенергії генеруючі підприємства галузі забезпечені приблизно на $60 \%$. Близько $40 \%$ ресурсів імпортується переважно з Росії (природний газ, ядерне паливо). 3 іншого боку, Україна має значний потенціал нафтогазових родовищ, які через відсутність інвестиційного капіталу не реалізується. Фонд виявлених перспективних на нафту і газ родовищ в Україні у 2013 р. нараховував 402 одиниці. Резервний фонд підготовлених до пошуково-розвідувального буріння структур в Україні становив 147 одиницю [14].

Вагоме місце в енергобалансі України відводиться вугіллю. Енергетичною стратегією України на період до 2030 р. передбачено зростання обсягів споживання вугілля до 98,7 млн. тон у 2015 р.; 107,6 млн. тон -2020 p.; 130,3 млн. тон - 2030 р. Та його задоволення за рахунок збільшення власного видобутку без суттєвого збільшення обсягу імпорту [15].

Енергетична безпека країни, котра покладена в основу цілепокладання Енергетичної стратегії ставить перед собою завдання: розвиток конкурентних відносин на ринках енергоносіїв; лібералізація та розвиток конкурентних відносин на ринках енергоресурсів; збільшення видобутку та виробництва власних енергоресурсів; а також збільшення обсягів енергії та енергопродуктів, видобутих із нетрадиційних і відновлюваних джерел енергії; диверсифікація зовнішніх джерел поставок енергетичних продуктів; створення умов для залучення до ПЕК приватних інвестицій, нових технологій і сучасного досвіду ефективної роботи та ін. Разом 3 тим викликають ряд питань такі дискусійні положення стратегії як то: задоволення попиту на основі середньорічного темпу зростання обсягів видобування вугілля на $71 \%$ і природного газу на $115 \%$. 3 одного боку, таким чином 
Україна зможе зменшити обсяги імпортування енергоресурсів, а 3 іншого порушуються основні принципи концепції сталого розвитку у частині дбайливого відношення до наявних природних ресурсів.

Сьогоднішня ситуація із добуванням та вивезенням вугілля із зони АТО (антитерористичної операції) зосередила увагу на стратегічних помилках, що були допущені при приватизації теплової генерації. У конкурсних умовах ключовою вимогою до претендентів було постачання українського вугілля на TEC. Це дало ДТЕК великі переваги і в результаті ця компанія отримала контроль над $67 \%$ теплової генерації. На думку експерта 3 енергетики, керівника Бюро комплексного аналізу та прогнозування С. Дяченко необхідно було диверсифікувати операторів, допустивши у даний сегмент діяльності стратегічних інвесторів, які мають можливість працювати на світових ринках [13].

Членство України в Європейському енергетичному співтоваристві вимагає досягнення 12\% за рахунок альтернативних джерел до 2020 р. Разом 3 тим темпи розвитку даного сегменту енергетики дозволяють прогнозувати не більше $1,57 \%$ до $2030 \mathrm{p}$.

Проектом Енергетичної стратегії до 2035 р. передбачено оптимізацію структури енергетичного балансу держави виходячи 3 вимог енергетичної безпеки та забезпечення частки відновлюваної енергетики на рівні 20\% (на період до 2035 р.). Судячи 3 приведеного прогнозного балансу, найбільшу питому вагу в альтернативному сегментів займатиме біоенергетика. Разом 3 тим, досягти в енергобалансі частки відновлювальний джерел енергії 14,2 \% до 2035 р. при нинішніх темпах технологічного оновлення буде вкрай важко.

Підписання Україною у 2011 p. Договору про входження до Енергетичного Співтовариства, відкрило перспективи для розвитку торговельних відносин українських і європейських газових трейдерів, згідно 3 правилами Третього енергетичного пакету. Це $\epsilon$ частиною міжнародних зобов'язань країн-учасниць Енергетичного співтовариства, а відтак i обов'язковим для України, та набуло чинності 1 січня 2015 року. Поряд із імплементацією нормативно-правової бази $€ \mathrm{C}$, що регламентує питання функціонування паливно-енергетичного комплексу, захисту навколишнього середовища, забезпечення вільної конкуренції, активізації використання відновлювальних джерел енергії Україна виводить свою загальну економічну безпеку на новий рівень, що гарантується регламентами Енергетичного Співтовариства. Поступова реалізація реформ у сфері паливно-енергетичного комплексу сприятиме розширенню енергетичної інфраструктури, надійності постачання енергоносіїв, підвищенню енергоефективності, появі конкурентних відносин і на цій основі врегулюванню тарифної політики тощо. Зміна організаційної структури енергетичних компаній через їх розукрупнення має на меті розмежування функцій продавця та покупця 
електроенергії та на цій основі створення у майбутньому повноцінного ринкового сегменту єдиного енергоринку СС.

Функціонування ринків енергоресурсів у країнах СС базується на принципах конкуренції, вільному та прозорому ціноутворенні, диверсифікації постачань. Це допомагає мінімізувати ряд ринкових та політичних ризиків.

Рівень енергетичної залежності країн ЄС складає близько $50 \%$. Дискусійні питання, пов'язані із підтриманням економічної безпеки та зменшенням залежності від зовнішніх постачальників знайшли своє відображення у Зеленій книзі «Свропейські стратегії сталої, конкурентоспроможної та безпечної енергетики». При цьому енергетична політика ЄC базується на трьох основних цілях: сталість, конкурентоспроможність, безпека енергозабезпечення. Таким чином розвинені країни розбудовують енергетичну інфраструктуру 3 розумінням того, що політика енергобезпеки має бути узгоджена у всіх сегментах ii впливу: добування енергоресурсів, транспортування, розподіл, використання, утилізація, відновлення.

На сьогодні ринок енергоресурсів України має достатньо високий рівень монополізації. Так частка незалежних газотрейдерів складає близько $13 \%$. А сегмент їх діяльності обмежується середніми та дрібними промисловими споживачами.

Згідно з правилами Третього енергетичного пакету СС передбачається впровадження моделі TSO (Transmission System Operator)oj, що базується на відокремленні діяльності із транспортування і розподілу газу від постачання. Це дасть можливість незалежним трейдерам напряму укладати угоди 3 постачальниками та покупцями, формуючи конкурентні відносини. Споживачам гарантується вільний вибір постачальників газу, доступ до об'єктів інфраструктури, моніторинг безпеки постачання тощо.

Цільова модель ринку газу СC (Gas Target Model), що була затверджена у 2912 р. Європейським форумом регулювання газового сектору передбачає розподіл ринку на зони, у межах яких забезпечується вільна конкурентна торгівля газом на підставі укладання контрактів спот. Кожна ринкова зона контактуватиме з іншими, а постачальники платитимуть за входження у зону та організацію доставки газу кінцевим споживачам. Передбачається, що торгівля природним газом між зонами сприятиме ціновому вирівнюванню. Діяльність газових трейдерів вийде за межі національних ринків, спонукатиме до коригування цін та інвестуванню у розвиток інфраструктури.

Мазовець А. вважає, що слід налагоджувати державно-приватне партнерство у нафтогазодобувному секторі. При цьому одним із факторів привабливості для інвесторів $\epsilon$ доступність геологічної інформації, приведення iї у відповідність до міжнародних стандартів. Удосконалити процедуру доступу до геологічної інформації можна завдяки створенню 
стійкої геоінформаційної системи європейського типу, побудові цифрових науково-технічних геологічних карт і поширенню публікацій, зробивши цю інформацію доступною через Інтернет [14].

Не зважаючи на можливі катастрофічні наслідки використання ядерної енергії, сьогодні пильна увага має приділятися розвитку АЕС. Україна забезпечена ураном на 50-70 років. Сьогодні в Україні працює чотири AEC, на яких діють 15 енергоблоків типу ВВЕР (водо-водяний енергетичний реактор) загальною потужністю 13880 МВт. За останнє десятиліття загальне щорічне виробництво електроенергії в Україні збільшилось, зросла й частка енерговиробітку на атомних електростанціях. Звичайно ми маємо тісну залежність від Російської Федерації, яка постачає збагачений уран. Для того, щоб збудувати АЕС за новими стандартами, орієнтованими на інших постачальників палива та інфраструктурних компонентів, знадобиться 15-20 років. Оскільки атомна енергетика знаходиться у державній власності, то іiі інтереси не лобіюються, на відміну від інших видів енергетики.

Експерти вважають, що сучасні атомні реактори не відповідають вимогам гарантованої безпеки, а радіоактивні відходи - вимогам екологічної чистоти. Ці аспекти відносяться до розряду пріоритетних при формування енергетичних стратегій ряду країн. Тому вихід вбачається у відродженні теплової енергетики на базі нафти, вугілля, сланцевого газу, біоресурсів.

Отже, підвищення рівня енергетичної безпеки України можливе на основі зростання: власного виробництва, у тому числі на основі розвитку альтернативних джерел енергії; диверсифікації зарубіжних постачальників 3 метою мінімізації політичних та ринкових ризиків.

Омельченко В. пропонує диверсифікацію шляхом: а) відновлення інтересу до скрапленого газу та LNG-терміналу, б) підтримки ініціативи Дональда Туска з переходу на єдині принципи ціноутворення в контрактах із «Газпромом», в) сприяння проектам «спільного інтересу» Енергетичного Співтовариства, будівництва інтерконекторів, г) розвитку альтернативної енергетики [16].

Науменко Д., на основі результатів оцінки Німецькою консультативною групою варіантів диверсифікації газопостачань пропонує наступні варіанти: 1) віртуальний реверс; 2) LNG-термінал (плаваючий та наземний); 3)»Білий потік» або хаб на Балканах; 4) нарощування власного видобутку; 5)скорочення споживання газу шляхом заміщення вугіллям [там само].

Диверсифікація джерел енергії, посилення транзитного потенціалу України та розвиток альтернативної енергетики потребують зваженої політики розвитку енергетичної інфраструктури. У стратегічному контекстів $\epsilon$ сенс розподілу інфраструктурних потреб галузі за такими напрямами:

1) Захист наявної енергетичної інфраструктури на випадок надзвичайних подій. Так у результаті військових дій на Сході України 
знищено та пошкоджено 1080 об'єктів енергетичного сектору. Оціночна сума, необхідна для відновлення системи енергоживлення в Донецькій області, становить за даними на лютий 2015 р. 476,6 млн. грн. (18,7 млн. євро);

2) Розбудова новітньої енергетичної інфраструктури відповідно до стратегічних планів розвитку різних сегментів енергетики. Так торгівля скрапленим газом потребує будівництва ЗПГ-терміналів для завантаження морських суден $\mathrm{i}$ терміналів регазифікації для постачання. Розвиток біоенергетики потребує формування системи логістичного забезпечення (інфраструктури) збирання біологічної сировини, маркетингу та транспортування до споживача тощо.

3) Модернізація газотранспортної системи України. За підрахунками компаніï Mott MacDonald (Велика Британія), модернізація i реконструкція газо-транспортної системи обійдеться в 4,8 млрд. дол. протягом 7 років.

4) Розширення транскордонної інфраструктури у контексті реалізації заходів, передбачених Третім енергетичним пакетом. Свропейське енергетичне співтовариство зацікавлене у залученні додаткових сховищ та транспортних мереж.

У вирішенні нагального питання посилення енергетичної незалежності України задіяні чимало провладних та бізнесових структур. У рамках узгодження різнопланових інтересів необхідно враховувати ряд стратегічних моментів:

- збільшення виробництва енергоресурсів з метою імпортозаміщення;

- створення стратегічних запасів вугілля, ядерного палива, нафти та газу;

- диверсифікація джерел постачання енергоресурсів;

- розвиток альтернативної енергетики;

- забезпечення автономної роботи об'єднаної енергосистеми України.

Разом 3 тим державна політика України у сфері енергетики характеризується неузгодженістю економічних та політичних інтересів на різних рівнях управління. Так проблемами енергоефективності профільні комітети та відомства почали перейматися тільки 3 настанням політичної кризи та коливаннями валютних курсів. Не узгоджені питання диверсифікації постачання енергоресурсів на основі співпраці 3 такими країнами як Азербайджан, Казахстан, Туркменістан, Алжир, Іран, країна Перської затоки тощо. Підвищення цін на енергоносії для населення здійснюється без врахування поточної ситуації, пов'язаної із падінням реальних доходів домогосподарств, а також відсутністю модернізації систем теплопостачання. Перелічені моменти не сприяють зміцненню економічної безпеки країни та породжують перекоси у перерозподілі грошових потоків, що генеруються у результаті реалізації енергоресурсів. Тому коригування державної політики 
енергобезпеки має відбуватися шляхом узгодження національних інтересів і стратегії євроінтеграції у розрізі таких напрямів:

- добування та відновлення енергоресурсів: нарощування частки відновлювальних джерел енергії та заміщення традиційних;

- транспортування і розподіл: модернізація ГТС з метою нарощування та повного використання їі потенціалу із залученням іноземного капіталу;

- використання: впровадження засад енергоефективності у всіх сферах споживання енергоресурсів шляхом залучення передових технологій та відповідної тарифної політики.

Тільки зважений підхід до вирішення критичних аспектів розвитку вітчизняної енергетики здатний продукувати результативність реформ.

Висновки. За умови політичної нестабільності роль та чутливість до загроз ПЕК, як гаранта економічної безпеки країни зростає. Поряд з іншими компонентами економічної безпеки, енергобезпека складає базис економічних відносин, створюючи умови для виробництва ВВП. Високий рівень залежності від зовнішнього постачання енергоносіїв стимулює розробку нових параметрів Енергетичної стратегії, спрямованих на диверсифікацію та розробку власних родовищ нафти, газу, вугілля, а також активізацію виробництва відновлювальних джерел енергії.

Науковою новизною даного дослідження $\epsilon$ формування комплексу стратегічних цілей енергетичної безпеки України та їх оцінка на основі виділення забезпечення мінімального і максимального рівня безпеки. Такий підхід дає можливість окреслити першочергові цілі енергетичної стратегії та пов'язати їх з наявним енергетичним потенціалом країни.

Перспективи подальших наукових розвідок торгаються співвідношень рівнів економічної безпеки на рівні держави та на рівні енергогенеруючих підприємств, діяльність яких є стратегічно важливою для економіки в цілому та вимагає обгрунтованих науково-методичних підходів виявлення загроз та їх подолання.

\section{Література:}

1.Земляний М.Г. До оцінки рівня енергетичної безпеки. Концептуальні підходи/ М.Г. Земляний// Стратегічна панорама. - 2009. - № 2. - С.56 - 64.

2.Лойко В.В. Енергетична безпека в контексті економічної безпеки / В.В. Лойко // Ефективна економіка. - 2013. - № 1

3.Микитенко В.В. На чому базується енергетична безпека держави/В.В. Микитенко// Вісник НАН України. - 2005. - № 3. - С.41-47.

4.Прейгер Д. Енергетична незалежність як складова економічної безпеки: український вимір [Електронний ресурс] / Д. Прейгер. - Режим доступу: http://eai.org.ua/magazine.

5.Сабадаш, В.В. Енергетична безпека України: конфліктність геополітичного вибору [Текст] / В.В. Сабадаш // Механізм регулювання економіки.-2011.-№ 2. - С. 52-59.

6.Суходоля О.М. Досвід реформування ринку електричної енергії в Україні // Стратегічні пріоритети. 2014. - №1. - С.59-68 
7. World Data Atlas [Electronic resource]. -Access mode: http: // knoema.ru/GESY2013/globalenergy-statistical-yearbook-2013?tsId=1000 \%20030

8.Потрійна енергетична залежність України // Інформаційно-аналітичний ресурс «Енергетичний ринок» . - 26.11.2014 р. - [Електронний ресурс]. - Режим доступу: http://energy-market.com.ua/enerhetychnyy-rynok/novyny/analityka/potriyna-enerhetychnazalezhnist-ukrayiny/

9. Проблема энергетической независимости Украины и пути ее решения // Всеукраїнська експертна мережа - [Електронний ресурс]. http://www.experts.in.ua/baza/analitic/index.php?ELEMENT_ID=10951

10. Видобуток природного газу в Україні: проблеми та перспективи. Матеріали засідання Експертної ради 3 питань газової промисловості та ринку природного газу при Міненерговугілля від 23.04.2013 року http://www.ngbi.com.ua/Ekspertna\%20Rada/vysnovky.pdf

12.Альтернативи газозабезпечення України: скраплений природний газ (СПГ) та нетрадиційний газ. - Аналітична доповідь Центру Разумкова// Національна безпека та оборона. - 2011. - № 9. С.2-47.

13. Дьяченко С. Костюковський Б. Брат біля воріт, або Кримські виклики енергетичній безпеці. - [Електронний ресурс]. - Режим доступу: http://geostrategy.org.ua /ua/component/k2/item/346-bkostyukovskiy-brat-bilya-vorit-abo-krimski-vikliki-energetichniybezpetsi

14.Мазовець А. Енергетична безпека має базуватись на видобутку власного газу [Електронний ресурс]. - Режим доступу: http://blog.liga.net/user/amyzovets/article/14935.aspx

15.Енергетична стратегія України на період до 2030 p. Схвалено розпорядженням Кабінету Міністрів України від 24 липня 2013 р. № 1071-р.

16.Тороп В. Енергетична безпека України: час реформ настав. Огляд конференції "Енергетична безпека України: виклики геополітичної кризи" http://ua.boell.org/uk/2014/06/12/energetichna-bezpeka-ukrayini-chas-reform-nastav-oglyadkonferenciyi-energetichna-bezpeka 